\title{
Priority directions of increasing the adaptivity of universities to the conditions of the digital economy
}

\section{Direções prioritárias para aumentar a adaptividade das universidades às condições da economia digital}

\section{Direcciones prioritarias para aumentar la adaptividad de las universidades a las condiciones de la economía digital}

\author{
Nataliia Kholiavko $^{1}$ (D) Olha Popelo $^{1}$ (D), Svitlana Tulchynska ${ }^{\text {iD }}$ \\ ${ }^{1}$ Chernihiv Polytechnic National University, Chernihiv, Ukraine. \\ ${ }^{2}$ National Technical University of Ukraine “Igor Sikorsky Kyiv Polytechnic Institute”, Kyiv, Ukraine. \\ Corresponding author: \\ Olha Popelo \\ Email: popelo.olha@gmail.com
}

How to cite: Kholiavko, N., Popelo, O., \& Tulchynska, S. (2021). Priority directions of increasing the adaptivity of universities to the conditions of the digital economy. Revista Tempos e Espaços em Educação, 14(33), e16383.

http://dx.doi.org/10.20952/revtee.v14i33.16383

\begin{abstract}
The digital economy forms a set of new challenges to the higher education system, namely: accelerating the pace of socio-economic transformations; transformation of information into a commodity and a productive force; large-scale digitalization of economic entities; virtualization of workplaces; active introduction of information and communication technologies; creation of a global information field; exacerbation of cybersecurity problems. In such conditions, the system of higher education and the activities of universities need to be adequately changed in order to ensure their competitiveness in the modern market of educational services. The article substantiates the need to increase the level of adaptability of higher education institutions to exogenous challenges. Under the category of adaptability, it is proposed to understand the desired property of the higher education system, which determines its ability to absorb shocks, adapt or reorganize in accordance with the challenges posed by the development of the digital economy. The main parameters of the adaptability of the higher education system to the digital economy are the degree of its resistance to external disturbances, the depth of response to them, the speed of recovery after crises, the degree of structural and functional reorganization, the possibility of continuing pre-board development trajectory. The purpose of the article is to formulate scientifically sound proposals to increase the level of adaptability of universities to the challenges of the digital economy. The authors of the set of such proposals are structured according to the selected types of adaptability: introversion and extraversion.
\end{abstract}


Keywords: Adaptation. Digital economy. Extraverted adaptability. Higher education. Introverted adaptability.

\section{RESUMO}

A economia digital configura um conjunto de novos desafios ao sistema de ensino superior, nomeadamente: acelerar o ritmo das transformações socioeconómicas; transformação da informação em mercadoria e força produtiva; digitalização em grande escala de entidades econômicas; virtualização de locais de trabalho; introdução ativa de tecnologias de informação e comunicação; criação de um campo de informação global; exacerbação dos problemas de segurança cibernética. Nessas condições, o sistema de ensino superior e as atividades das universidades precisam ser adequadamente alteradas de forma a garantir sua competitividade no moderno mercado de serviços educacionais. $O$ artigo fundamenta a necessidade de aumentar o nível de adaptabilidade das instituições de ensino superior aos desafios exógenos. Na categoria de adaptabilidade, propõe-se compreender a propriedade desejada do sistema de ensino superior, que determina a sua capacidade de absorver choques, adaptar-se ou reorganizar-se de acordo com os desafios colocados pelo desenvolvimento da economia digital. Os principais parâmetros da adaptabilidade do sistema de ensino superior à economia digital são o grau de resistência às perturbações externas, a profundidade da resposta a elas, a velocidade de recuperação após as crises, o grau de reorganização estrutural e funcional, a possibilidade de continuando a trajetória de desenvolvimento do pré-embarque. O objetivo do artigo é formular propostas cientificamente sólidas para aumentar o nível de adaptabilidade das universidades aos desafios da economia digital. Os autores do conjunto dessas propostas são estruturados de acordo com os tipos de adaptabilidade selecionados: introversão e extroversão.

Palavras-chave: Adaptabilidade extrovertida. Adaptabilidade introvertida. Adaptação. Economia digital. Ensino superior.

\section{RESUMEN}

La economía digital configura un conjunto de nuevos desafíos para el sistema de educación superior, a saber: acelerar el ritmo de las transformaciones socioeconómicas; transformación de la información en mercancía y fuerza productiva; digitalización a gran escala de entidades económicas; virtualización de lugares de trabajo; introducción activa de tecnologías de la información y la comunicación; creación de un campo de información global; exacerbación de los problemas de ciberseguridad. En tales condiciones, el sistema de educación superior y las actividades de las universidades deben modificarse adecuadamente para asegurar su competitividad en el mercado moderno de servicios educativos. El artículo fundamenta la necesidad de incrementar el nivel de adaptabilidad de las instituciones de educación superior a desafíos exógenos. Bajo la categoría de adaptabilidad, se propone entender la propiedad deseada del sistema de educación superior, que determina su capacidad para absorber choques, adaptarse o reorganizarse de acuerdo con los desafíos que plantea el desarrollo de la economía digital. Los principales parámetros de la adaptabilidad del sistema de educación superior a la economía digital son el grado de resistencia a las perturbaciones externas, la profundidad de respuesta a las mismas, la velocidad de recuperación después de las crisis, el grado de reorganización estructural y funcional, la posibilidad de continua trayectoria de desarrollo previo a la placa. El propósito del artículo es formular propuestas científicamente sólidas para aumentar el nivel de adaptabilidad de las universidades a los desafíos de la economía digital. Los autores del conjunto de tales propuestas se estructuran según los tipos de adaptabilidad seleccionados: introversión y extraversión.

Palabras clave: Adaptabilidad extravertida. Adaptabilidad introvertida. Adaptación. Economía digital. Educación superior. 


\section{INTRODUCTION}

The development of the digital economy is characterized by the accelerated transformation of socio-economic relations, which puts forward new demands on economic actors. The dynamics of such changes increase the uncertainty of the exogenous environment and cause risks. The stability of the functioning of socio-economic systems in these conditions directly depends on their adaptability.

The concept of adaptability is interdisciplinary, widely used in biological, mathematical, sociological, cybernetic, as well as in a number of technical and economic sciences. The word "adaptability" comes from the Latin "adaptio" and means "adaptation". For the first time in scientific use, this term appeared in biology, later penetrating other areas of research. In the scientific literature, the concept of adaptability is often used along with the term "adaptation". However, despite some similarities, these categories are not identical. In particular, adaptation is the process of adapting a system or its individual subsystems / components / elements to changes in the environment. While adaptability is seen as a property or characteristic of the socio-economic system. We hold the same position in this study.

\section{LITERATURE REVIEW}

A number of scientific publications are devoted to the study of various aspects of the transformation of higher education institutions in the context of digitalization of society and the processes of digitalization in general, including: Bazhenkov et al. (2021); Kychko \& Zhygalkevych (2021); Lazarenko \& Saloid (2020); Samiilenko et al. (2021); Samoilovych et al. (2021) and others.

Most of the articles are aimed at studying the peculiarities of changing the educational process, the introduction of information and communication technologies and the latest digital tools for interaction with students (Levin, 1992; Abrosimova, 2019; Faleev, 2018; Abrosimova, 2020; Arkorful, 2015; Mostert, 2009; Mukama, 2008). The concept of a digital university is not new and has been considered by scientists since 2012 (McCluskey \& Winter, 2014; Jones \& Goodfellow, 2012, Johnston, 2018; Gehrke, 2014). However, the challenges posed by the COVID-19 pandemic have formed a set of new requirements for universities and the pace of their digitalisation. This, in turn, necessitated a rethinking and modernization of the concept of the digital university (Neborsky, 2020; Habib, 2021). Key aspects of the development of the higher education system in the conditions of information economy formation are revealed in the works (Djakona, 2020; Zhavoronok \& Kozlovskyi, 2020). Despite the availability of thorough research on the development of higher education institutions in modern conditions, in-depth study requires the identification of priority areas for improving the adaptability of universities to the challenges of digitalization of the national economy.

In the opinion of the authors of the article, first of all it is necessary to distinguish between the categories "adaptability" and "adaptation", which are not appropriate to identify. The substantiation of this statement is given in fig. 1. Adaptability, as a property of the socio-economic system, determines its ability to adapt, structural reorganization, transformation while maintaining its basic functions and characteristics. 
Figure 1. Morphological analysis of the concepts of "adaptation" and "adaptability".

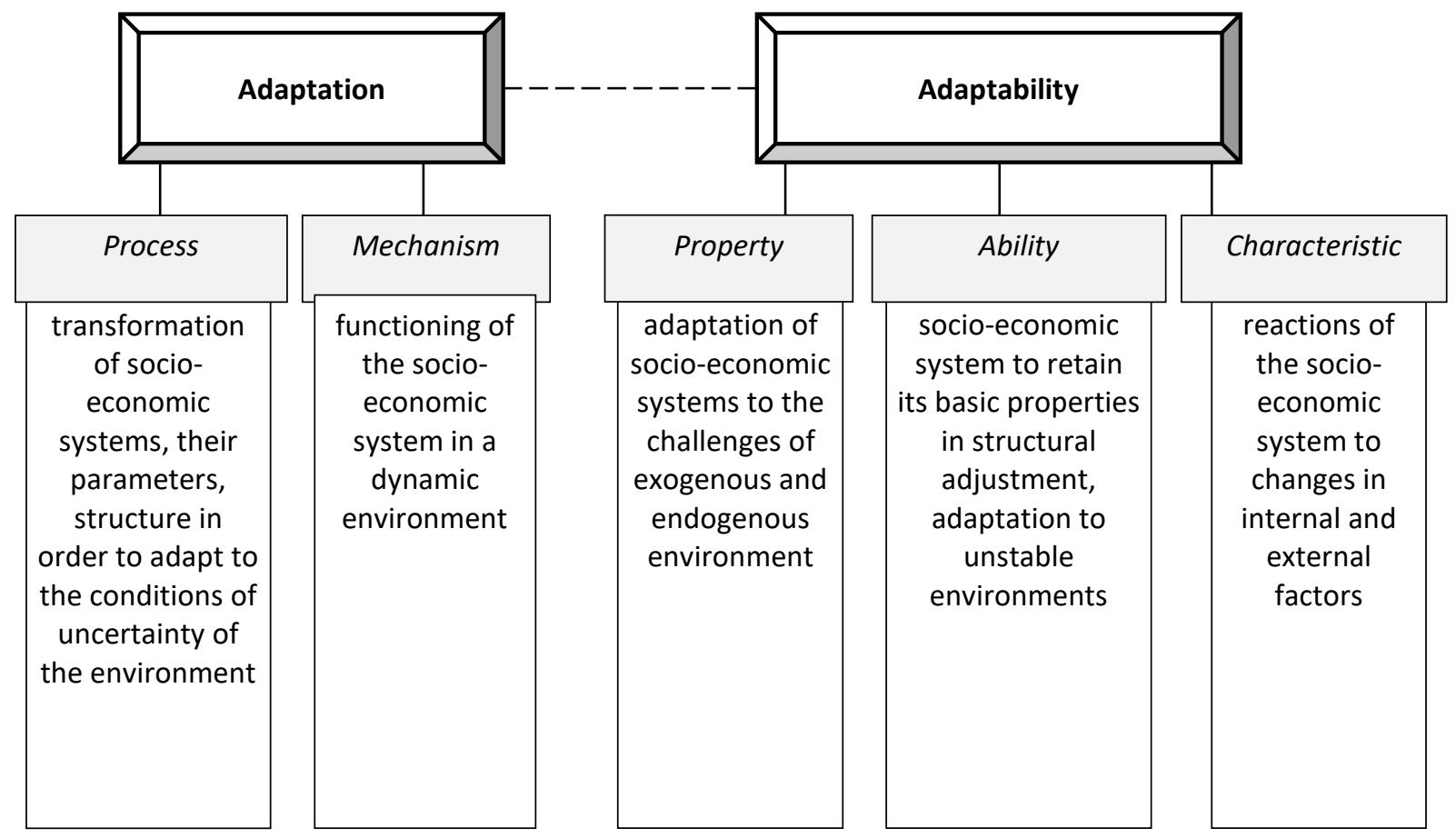

In the opinion of the authors, interpreting adaptability should be based not only on external but also on internal changes. This is especially true in the study of complex open socio-economic systems, which include the system of higher education. Because the system as a whole for selfpreservation must be able to adapt to radical changes in its structural elements or subsystems. The adequacy and speed of the system's response to such changes directly affects its viability.

Thus, the analysis of the category "adaptability" reveals a three-dimensional approach, namely: first, structural, secondly, functional, thirdly, behavioral. This allows you to take into account both the essential points and the set of relationships between subsystems of different levels and with agents of the environment; both exogenous and endogenous parameters of transformations. We consider it quite justified, because in this case the criteria of changes in the environment are taken into account, their causes are established, the nature and extent of structural changes aimed at ensuring the sustainability of the socio-economic system in turbulent conditions. The property of adaptability allows the socio-economic system to balance with the pace of development of the external environment, changing or maintaining its own trajectory in accordance with the action of various factors.

\section{METHODOLOGY}

Thus, the interdisciplinary analysis proved that scientists, whose works have been previously studied, often in different related sciences mainly use three approaches: - "shock response" involves reducing the possibility of rapid adjustment of the economy and its recovery in a budget deficit, stagflation and unemployment; - "shock absorption" - substantiates that the tools of shock absorption are mechanisms of endogenous regulation that can reduce the negative impact of shock on the system, such tools may include highly skilled labor; - "shock avoidance" - implies that this aspect of resilience is a mandatory and natural component of the vulnerability of economic systems.

Considering the national system of higher education as a socio-economic system, we consider the above approaches to the definition applicable to our study. It is appropriate to talk 
about ensuring the adaptability of the higher education system, as this system is endowed with such properties as openness, complexity, ability to self-organize and resistance to external disturbances.

In addition, this system has accumulated a huge information base, created a network of information channels. Moreover, it is not only about the ability of staff to learn throughout life, but also about the ability of the socio-economic system to self-study as a basis for its effective functioning.

\section{RESULTS AND DISCUSSION}

A detailed analysis of the internal content of the category of adaptability of the higher education system to the conditions of the digital economy is presented in table 1.

Table 1. The essence of the adaptability of the higher education system to the conditions of the digital economy (according to the approach of Martin R. and Sanli R.).

\begin{tabular}{|c|c|c|}
\hline Question & General aspects of the definition & Specific aspects of the definition \\
\hline adaptability of what? & $\begin{array}{l}\text { - defining characteristics, critical signs of } \\
\text { system adaptability; } \\
\text { - approach to measuring system } \\
\text { adaptability; } \\
\text { - criteria for determining the structural and } \\
\text { functional restructuring of the system in } \\
\text { response to shock perturbations }\end{array}$ & $\begin{array}{l}\text { Adaptability is the ability of the higher education } \\
\text { system to transform under the influence of the } \\
\text { digital economy without losing or radically } \\
\text { changing the system-forming (structural and } \\
\text { functional-target) properties. } \\
\text { Taking into account the dialistic nature of } \\
\text { adaptability. }\end{array}$ \\
\hline adaptability to what? & $\begin{array}{l}\text { - nature, intensity and duration of external } \\
\text { disturbances; } \\
\text { - forms of shock perturbations and the } \\
\text { ability of the system to withstand various } \\
\text { of them }\end{array}$ & $\begin{array}{l}\text { Adaptability is the ability of a higher education } \\
\text { system to withstand, absorb, adapt and reorganize } \\
\text { in response to the challenges posed by the digital } \\
\text { economy. } \\
\text { Taking into account the two-way impact of higher } \\
\text { education and the digital economy. }\end{array}$ \\
\hline how? & $\begin{array}{l}\text { - methods or means by which adaptability } \\
\text { is formed; } \\
\text { - mechanisms of system response to shock } \\
\text { perturbations; } \\
\text { - factors influencing such mechanisms and } \\
\text { processes }\end{array}$ & $\begin{array}{l}\text { The need to develop a mechanism determined by } \\
\text { exogenous and endogenous factors to ensure the } \\
\text { adaptability of the national higher education } \\
\text { system in the development of the digital economy } \\
\text { is urgent. }\end{array}$ \\
\hline with what result? & $\begin{array}{l}\text { - duration and nature of the system after } \\
\text { external disturbances; } \\
\text { - the ability of the system to return to the } \\
\text { pre-shock state and continue the } \\
\text { trajectory of development }\end{array}$ & $\begin{array}{l}\text { Strategic orientation of the mechanism of ensuring } \\
\text { the adaptability of the higher education system to } \\
\text { achieve the pre-crisis state with the continuation of } \\
\text { the growing trend of development. }\end{array}$ \\
\hline
\end{tabular}

In their study, the authors proceed from the hypothesis of the existence of two types of adaptability: introversion and extraversion (Fig. 2). 
Figure 2. Structural and logical scheme of types of adaptability of the national system of higher education.

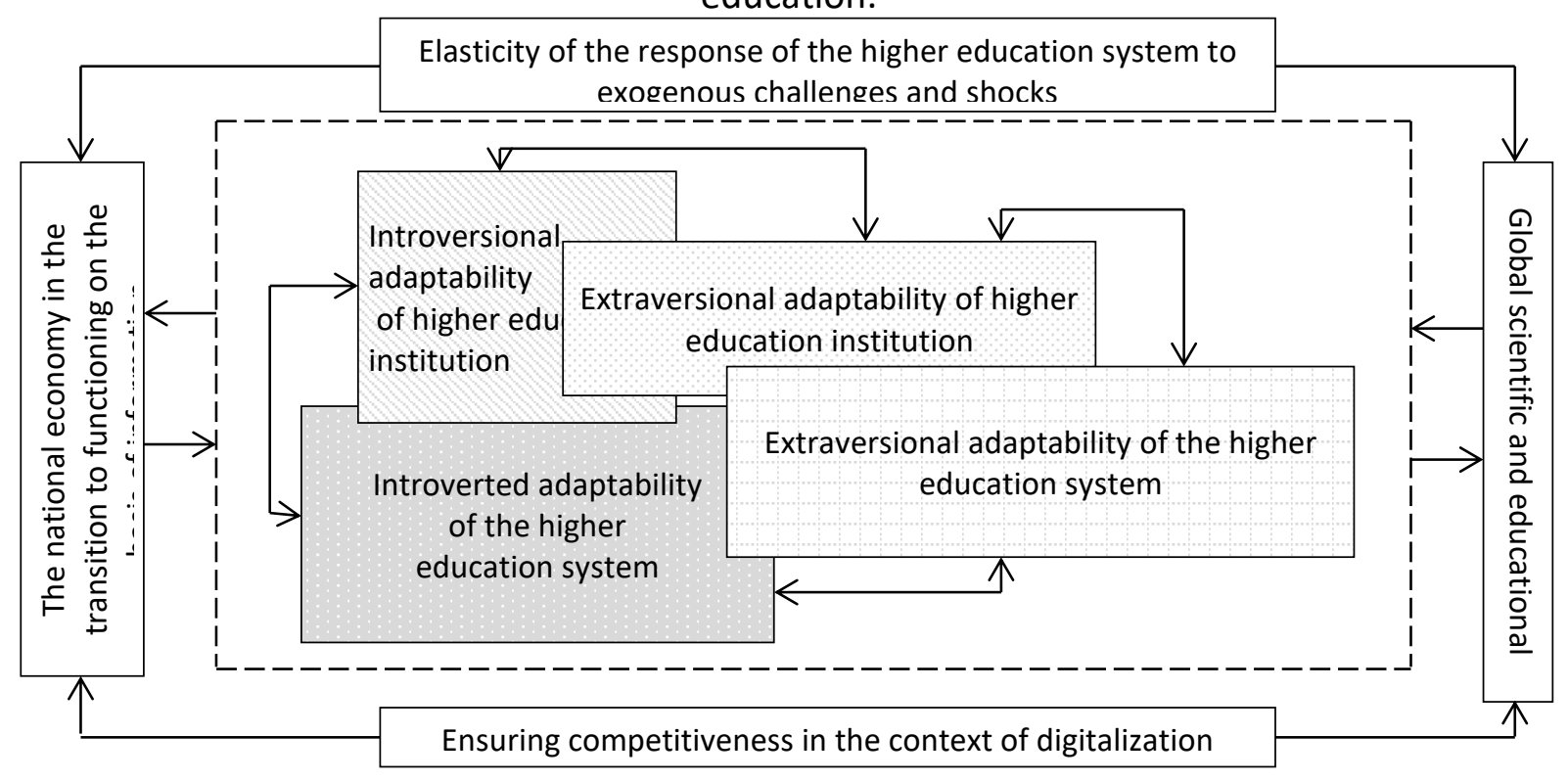

In our opinion, the extraverted adaptability of the higher education system is formed in response to the trend of the global information field, and the introverted adaptability is formed in response to the new challenges caused by the digitalization of the national economy. Increasing the extraversional adaptability of the university means intensifying the processes of introduction of modern information and communication technologies, development of tools and methods of distance learning, expanding students' access to mass online courses (MEP) and others. To ensure introverted adaptability, universities are expanding programs to develop students' digital skills, increase their level of information literacy, and master practical skills in working with innovative technologies.

Increasing the level of adaptability of higher education and universities to the conditions of the digital economy is implemented in the following areas:

1) synchronization with the priorities of the state innovation, scientific and technical, educational policy, as well as harmonization with international, European programs in the fields of higher education and science;

2) stimulating cooperation between universities and business in educational and research activities;

3) ensuring the effectiveness of the model of financing higher education with the diversification of sources and differentiation of paid services while expanding the financial autonomy of universities;

4) intensification of international scientific and educational cooperation of universities as a reaction to the requirements of globalization and internationalization of the educational space;

5 ) increasing the effectiveness of universities: - educational activities (indicator - the level of competitiveness of graduates in the labor market), - research activities (indicator - the volume of commercialization of patented inventions and developments), - innovation activity (indicator indicators of transfer of generated innovations to the real sector of the economy),

- international activities (indicator - the number of joint research and educational projects funded by international grants);

6) accelerating the pace of implementation of modern information and communication technologies;

7) guaranteeing the effective functioning of the intellectual property protection system; 
8) introduction of effective motivational mechanisms for the development of cooperation of higher education institutions with the business sector (this will strengthen the relationship between them, which will increase the adaptability of their subjects to external disturbances formed by the digitalization of the national economy).

The directions outlined above in terms of types of adaptability of the higher education system and universities to the current challenges of the digital economy are visualized in Fig. 3.

Figure 3. Structure of measures to ensure the adaptability of the higher education system and universities to the challenges of the digital economy.

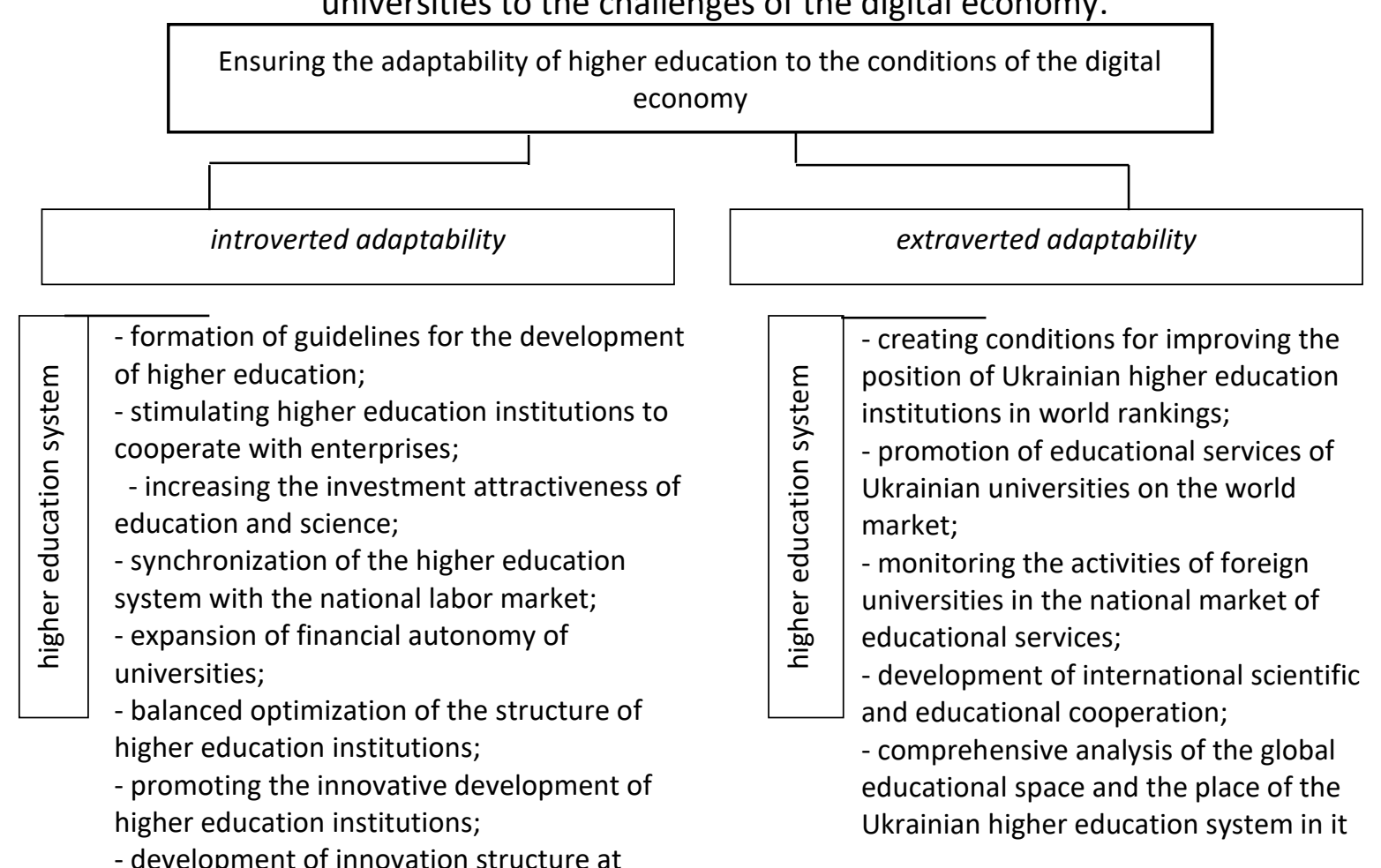

- development of innovation structure at universities

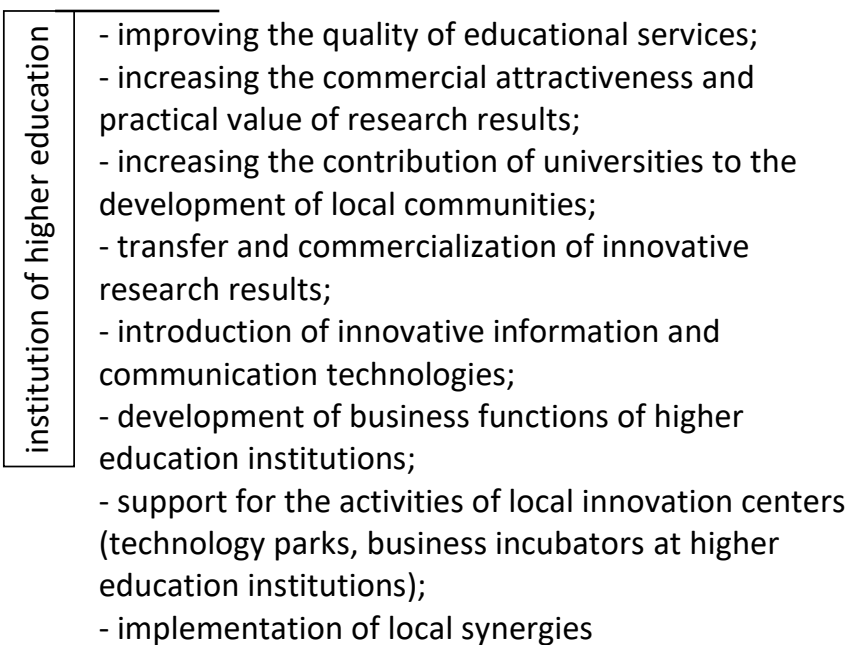

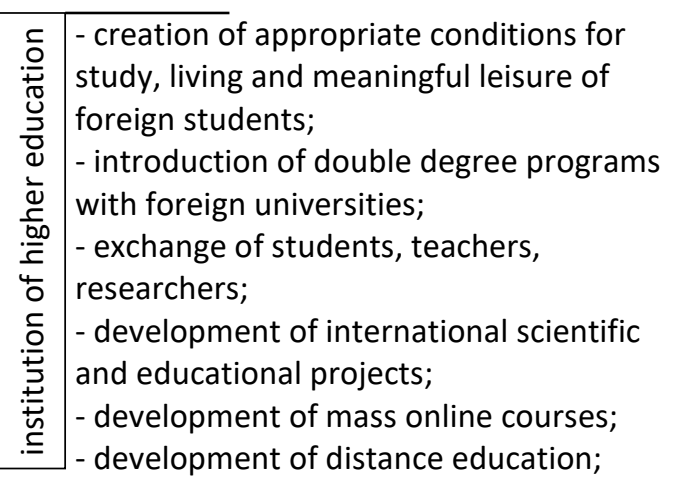

- conducting marketing campaigns abroad by higher education institutions

From the point of view of management theory, ensuring the successful implementation of measures to increase the level of adaptability of universities to the challenges of the digital economy requires a clear division of responsibilities between key stakeholders, specification of tools, required support and current management actions - table. 2. 
Table 2. Detailing the process of achieving the goals of higher education system development in the digital economy.

\begin{tabular}{|c|c|c|c|c|}
\hline Strategic goal & Subjects & Functional support & Resource provision & Tools \\
\hline 1 & 2 & 3 & 4 & 5 \\
\hline \multirow[t]{2}{*}{$\begin{array}{l}\text { Adequacy to the } \\
\text { requirements of } \\
\text { the digital } \\
\text { economy }\end{array}$} & $\begin{array}{l}\text { Public sector } \\
\text { entities; public } \\
\text { sector actors }\end{array}$ & $\begin{array}{l}\text { Planning, regulation, } \\
\text { motivation, analysis }\end{array}$ & $\begin{array}{l}\text { Regulatory, } \\
\text { financial, } \\
\text { information }\end{array}$ & $\begin{array}{c}\text { Regulations, } \\
\text { financing, subsidies } \\
\text { from the state } \\
\text { budget }\end{array}$ \\
\hline & $\begin{array}{c}\text { Entities in the higher } \\
\text { education sector }\end{array}$ & $\begin{array}{l}\text { Planning, organization, } \\
\text { motivation, control }\end{array}$ & $\begin{array}{c}\text { Personnel, financial, } \\
\text { logistical, } \\
\text { informational }\end{array}$ & $\begin{array}{c}\text { Tools of material and } \\
\text { moral motivation; } \\
\text { strategic planning }\end{array}$ \\
\hline \multirow[t]{2}{*}{$\begin{array}{l}\text { Improving the } \\
\text { competitiveness } \\
\text { of higher } \\
\text { education } \\
\text { institutions }\end{array}$} & $\begin{array}{l}\text { Entities in the higher } \\
\text { education sector }\end{array}$ & Planning, organization & $\begin{array}{c}\text { Financial, } \\
\text { personnel, logistical }\end{array}$ & $\begin{array}{l}\text { Prognostication; } \\
\text { benchmarking; } \\
\text { development } \\
\text { system; Targeted } \\
\text { financing }\end{array}$ \\
\hline & Public sector entities & Motivation, planning, control & $\begin{array}{l}\text { Financial, } \\
\text { informational, } \\
\text { logistical }\end{array}$ & $\begin{array}{l}\text { Financing, strategic } \\
\text { planning, consulting }\end{array}$ \\
\hline \multirow{3}{*}{$\begin{array}{l}\text { Increasing the } \\
\text { investment } \\
\text { attractiveness of } \\
\text { higher education }\end{array}$} & $\begin{array}{c}\text { Entities in the higher } \\
\text { education sector }\end{array}$ & $\begin{array}{l}\text { Planning, organization, } \\
\text { analysis, control }\end{array}$ & $\begin{array}{c}\text { Personnel, } \\
\text { information, } \\
\text { financial, logistical }\end{array}$ & $\begin{array}{c}\text { Information } \\
\text { databases and } \\
\text { networks; financing }\end{array}$ \\
\hline & Public sector entities & $\begin{array}{l}\text { Regulation, motivation, } \\
\text { analysis }\end{array}$ & $\begin{array}{l}\text { Information, } \\
\text { regulatory and legal }\end{array}$ & $\begin{array}{l}\text { Consulting, expert } \\
\text { assistance, } \\
\text { regulations }\end{array}$ \\
\hline & Entrepreneurs & Organization, analysis & $\begin{array}{l}\text { Financial, } \\
\text { informational }\end{array}$ & $\begin{array}{l}\text { Information bases; } \\
\text { forecasting the need } \\
\text { for innovation; } \\
\text { evaluation of the } \\
\text { effectiveness of the } \\
\text { implementation of } \\
\text { innovative } \\
\text { developments in } \\
\text { production }\end{array}$ \\
\hline
\end{tabular}

Table 2 (continued). Detailing the process of achieving the goals of higher education system development in the digital economy.

\begin{tabular}{|c|c|c|}
\hline Influencing factors & Achievement criteria & Current management actions \\
\hline 6 & 7 & 8 \\
\hline $\begin{array}{l}\text { Geopolitical situation; budget deficit; } \\
\text { transformation of political priorities }\end{array}$ & $\begin{array}{l}\text { Balance of the structure of financing } \\
\text { of higher education institutions; } \\
\text { compliance with global trends in } \\
\text { higher education; harmonization of } \\
\text { the national legal framework in the } \\
\text { field of higher education with } \\
\text { European norms }\end{array}$ & $\begin{array}{l}\text { Monitoring of parameters of higher } \\
\text { education system development; } \\
\text { consulting support; expansion of } \\
\text { institutional autonomy of higher } \\
\text { education institutions; public } \\
\text { monitoring of higher education } \\
\text { development; public monitoring of } \\
\text { the implementation of state } \\
\text { programs in the field of higher } \\
\text { education }\end{array}$ \\
\hline $\begin{array}{l}\text { Exacerbation of competition in the } \\
\text { market of educational services; } \\
\text { reduction of funding; violation of } \\
\text { communication channels }\end{array}$ & $\begin{array}{l}\text { Employment of graduates; } \\
\text { synchronization of interaction with } \\
\text { stakeholders; demand for university } \\
\text { performance in the national economy }\end{array}$ & $\begin{array}{l}\text { Evaluation of the achievement of } \\
\text { intermediate results; regular } \\
\text { monitoring of business and society } \\
\text { inquiries; informatization of the } \\
\text { educational process; introduction of } \\
\text { information and communication } \\
\text { technologies; publication of } \\
\text { university activities (including } \\
\text { through web resources) }\end{array}$ \\
\hline
\end{tabular}


Transformations of the global educational space; outflow of scientific personnel abroad

Positions of Ukrainian higher education institutions in international rankings of universities; number of foreign students; parameters of academic mobility

Socio-economic imbalances in the country

Decrease in innovative activity of business in the country

Changing the priorities of state development

Excessive tax pressure on business (including small business)
Places in the rankings of world universities, which are occupied by separate and purposefully supported by the state higher education institutions; dynamics of demand for services of domestic universities Diversification of funding sources; increase in funding from the business sector; revenues from the commercialization of research results

The level of innovation activity in the country; dynamics of volumes of introduction of innovative types of production, innovative information and communication technologies, new technological processes.

The level of business satisfaction with products received from higher education institutions; duration of cooperation between enterprises and universities
Study of the methodology of

international rankings of universities, analysis of the leaders of such rankings, identification of promising areas of modernization of Ukrainian higher education institutions to enter the world rankings, development of relevant tactical plans (programs), resource provision for their implementation

Identification of three to five flagship universities, information, financial and logistical support for their movement to be included in international rankings

Implementation of measures for the formation of commercially attractive scientific developments;

commercialization of innovations; development of innovation infrastructure of universities Implementation of measures to inform about the prospects of business cooperation with universities; support of information platforms on the results of university research; harmonization of the provisions of the current legislation in terms of regulating the activities of higher education institutions Informing about the needs of the business sector; research funding; investing in innovative projects; formulating recommendations to universities on the developments in demand in the market

In their study, the authors assume that the successful implementation of measures to increase the adaptability of higher education and universities to the challenges of the digital economy requires an integrated approach, ie should be implemented at different levels. In particular, macro-dimension (identification of conceptual directions of development), mesodimension (target realization of strategic goals), micro-dimension (functional realization of tasks or operational goals) are distinguished. This takes into account a set of factors, namely:

- factors of state regulation - creating a favorable investment climate for the generation and provision of education; promoting the growth of investment in intellectual capital; easing the tax burden on higher education institutions and promoting their financial self-sufficiency;

- factors of intellectualization - the development of creative forms of education and the introduction of new educational technologies, improving the quality of education; growth of labor market requirements for qualification characteristics and competencies of employees; increasing the demand of economic entities for intellectual work; the growing role of human capital in the socio-economic development of the country;

- factors of globalization - increasing the competitiveness of highly qualified professionals in the international labor market; deepening international cooperation, intensifying competition and accelerating intellectual migration; 
- factors of structural transformation - diversification of forms of educational activity; increasing the level of employment in science-intensive industries; development of educational and qualification structure of staff; increase academic mobility.

\section{CONCLUSION}

The article defines the essence of adaptability as a property of the higher education system that determines its ability to absorb shocks, adapt or reorganize in accordance with the challenges posed by the digital economy. Emphasis should be placed on the need to preserve the systemforming features and basic functions of the national system of higher education.

The system of higher education refers to adaptive systems with automatic optimization of management quality, with the possibility of self-organization and self-learning. Ensuring the adaptability of the higher education system to the conditions of the digital economy will allow: to optimize the activities of higher education institutions as elements of the educational system in conditions of incomplete input information; to promote the growth of the level of competitiveness of the national system of higher education in the global market of educational services by increasing the level of its adequacy to world trends; increase the level of resilience of the system to turbulent socio-economic conditions; increase the viability of the system in a dynamic exogenous environment. The main parameters of the adaptability of the higher education system are the ability to withstand external disturbances, the speed of recovery after crises, the assessment of the intensity of structural and functional reorganization, the ability to continue the pre-board trajectory of development.

The implementation of the measures proposed in the article is aimed at: convergence of education, science and business; ensuring diversification of sources of funding for higher education institutions; increasing the investment attractiveness of research results of universities; increasing the international competitiveness of higher education institutions. The formation of the adaptability of the national system of higher education will ensure its viability in the dynamic exogenous conditions of digitalization of the national economy.

Authors' Contributions: Kholiavko, N.: conception and design, acquisition of data, analysis and interpretation of data, drafting the article, critical review of important intellectual content; Popelo, O.: conception and design, acquisition of data, analysis and interpretation of data, drafting the article, critical review of important intellectual content; Tulchynska, S.: conception and design, acquisition of data, analysis and interpretation of data, drafting the article, critical review of important intellectual content. The authors have read and approved the final version of the manuscript.

Ethics Approval: Not applicable.

Acknowledgments: Not applicable.

\section{REFERENCES}

Abrosimova, A. A. (2020). Digital Literacy and Digital Skills in University Study. International Journal of Higher Education, 9(8), 52-58. https://doi.org/10.5430/ijhe.v9n8p52

Abrosimova, G., Kondrateva, I., Voronina, E., \& Plotnikova, N. (2019). Blended learning in university education. Humanities and Social Sciences Reviews, 7(6), 6-10. https://doi.org/10.18510/hssr.2019.762

Arkorful, V., \& Abaidoo, N. (2015). The role of e-learning, advantages and disadvantages of its adoption in higher education. International Journal of Instructional Technology and Distance Learning, 12(1), 29-42.

Faleev, M. D., \& Faleeva, E. V. (2018). The use of digital technologies in the educational process of "elite education" of the Far Eastern State University of Railway Engineering. Modern educational process: questions of theory and practice proceedings of the Interregional Scientific and Methodological Conference, 76-79.

Gehrke, S. (January 2014). The Idea of the Digital University: Ancient Traditions, Disruptive Technologies and the Battle for the Soul of Higher Education by Frank Bryce McCluskey and Melanie Lynn Winter (review). The Review of Higher Education, 37(4), 565-567. 
Habib, M.N., Jamal, W., Khalil, U. et al. (2021). Transforming universities in interactive digital platform: case of city university of science and information technology. Educ Inf. Technol., 26, 517-541. https://doi.org/10.1007/s10639$\underline{020-10237-w}$

Johnston, B., MacNeill, S., \& Smyth, K. (2018). The Digital University: An Impoverished Concept. In: Conceptualising the Digital University. Digital Education and Learning. Palgrave Macmillan, Cham. https://doi.org/10.1007/978-3-319$\underline{99160-3 \quad 2}$

Jones, C., \& Goodfellow, R. (July 2012). The "Digital University": Discourse, Theory, and Evidence. International Journal of Learning and Media, 4(3-4), 59-63.

Kholiavko, N., Djakona, A., Dubyna, M., Zhavoronok, A., Lavrov, R. (2020). The Higher Education Adaptability To The Digital Economy. Bulletin of the National academy of sciences of the Republic of Kazakhstan, 4(386), $294-306$. https://doi.org/10.32014/2020.2518-1467.130

Kholiavko, N., Popelo, O., Bazhenkov, I., Shaposhnykova, I., Sheremet, O. (2021). Information and communication technologies as a tool of strategy for ensuring the higher education adaptation to the digital economy challenge. IJCSNS International Journal of Computer Science and Network Security, 21(8), 187-195.

https://doi.org/10.22937/IJCSNS.2021.21.8.25

Kholiavko, N., Zhavoronok, A., Marych, M., Viknianska, A., Kozlovskyi, S., \& Herasymiuk K. (2020). Countries Disposition In The Global Scientific And Educational Area: Management And Clustering. International Journal of Management (IJM), 11(5), 400-415.

Lazarenko, I., Saloid, S., Tulchynska, S., Kyrychenko, S., Tulchinskiy, R. (2020). Necessity of implementating data science course in economics curricula. Information technologies and teaching aids, 4(78), 132-144.

https://doi.org/10.33407/itlt.v78i4.3505

Levin, J., Waugh, M., Chung, H. K., \& Miyake, N. (1992). Activity cycles in educational electronic networks. Interactive Learning Environments, 2(1), 3-13. https://doi.org/10.1080/1049482920020102

Mostert, M., \& Quinn, L. (2009). Using ICTs in teaching and learning: Reflections on professional development of academic staff. International Journal of Education and Development using ICT, 5(5), 72-84.

Mukama, E., \& Andersson, S. B. (2008). Coping with change in ICT-based learning environments: Newly qualified Rwandan teachers' reflections. Journal of Computer Assisted Learning, 24(2), 156-166.

Neborsky, E.V., Boguslavsky, M.V., Ladyzhets, N.S., \& Naumova, T.A. (2020). Digital university: rethinking the model framework within stakeholder theory. World of Science. Pedagogy and psychology, 6(8), 620.

Popelo, O., Kychko, I., Tulchynska, S., Zhygalkevych, Zh., Treitiak, O. (2021). The Impact of Digitalization on the Forms Change of Employment and the Labor Market in the Context of the Information Economy Development. IJCSNS International Journal of Computer Science and Network Security, 21(5), 160-167. https://doi.org/10.22937/IJCSNS.2021.21.5.23

Samiilenko, H., Popelo, O., Khudolei, V., Mashnenkov, K., Derkachenko, Yu. (2021). Transformational processes of clustering in digital economy. Laplage em Revista (International), 7, 691-702. https://doi.org/10.24115/S2446622020217Extra-C1106p.691-702.

Samoilovych, A., Garafonova, O., Popelo, O., Marhasova, V., \& Lazarenko, Yu. (2021). World experience and ukrainian realities of digital transformation of regions in the context of the information economy development. Financial and credit activity: problems of theory and practice, 3(38), 316-325. https://doi.org/10.18371/fcaptp.v3i38.237462

Received: 31 July 2021 | Accepted: 2 October 2021 | Published: 2 November 2021

This is an Open Access article distributed under the terms of the Creative Commons Attribution License, which permits unrestricted use, distribution, and reproduction in any medium, provided the original work is properly cited. 